\title{
Oceanography
}

CITATION

Brewer, P.G., and A.F. Hofmann. 2014. A plea for temperature in descriptions of the oceanic

oxygen status. Oceanography 27(1):160-167, http://dx.doi.org/10.5670/oceanog.2014.19.

DOI

http://dx.doi.org/10.5670/oceanog.2014.19

COPYRIGHT

This article has been published in Oceanography, Volume 27, Number 1, a quarterly journal of The Oceanography Society. Copyright 2014 by The Oceanography Society. All rights reserved.

USAGE

Permission is granted to copy this article for use in teaching and research. Republication, systematic reproduction, or collective redistribution of any portion of this article by photocopy machine, reposting, or other means is permitted only with the approval of The Oceanography Society. Send all correspondence to: info@tos.org or The Oceanography Society, PO Box 1931, Rockville, MD 20849-1931, USA. 
SPECIAL ISSUE ON CHANGING OCEAN CHEMISTRY" ANTHROPOCENE: THE FUTURE...SO FAR

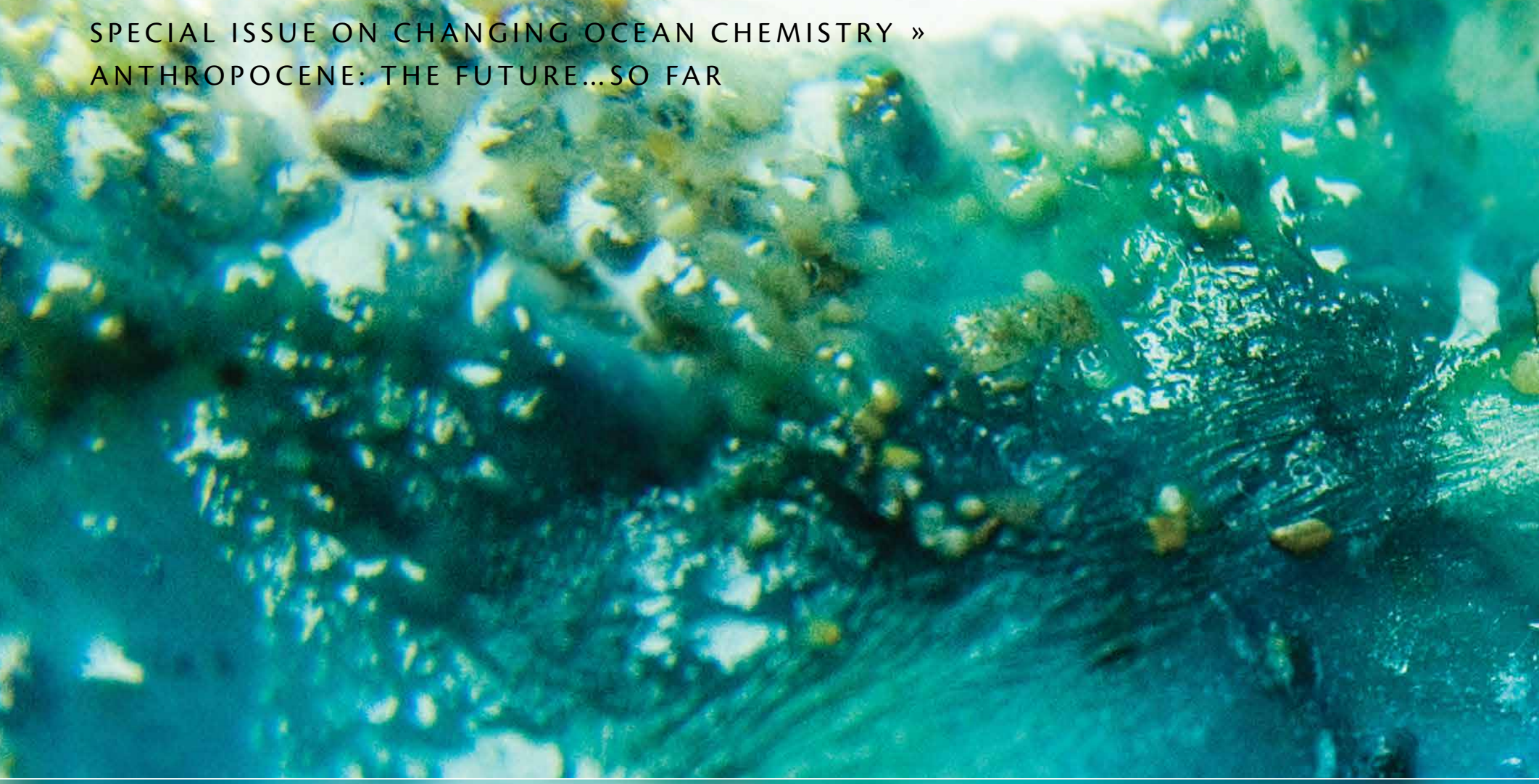

\section{A Plea for Temperature in \\ Descriptions of the Oceanic Oxygen Status}

BY PETER G. BREWER AND ANDREAS F. HOFMANN 
ABSTRACT. For over 50 years, the ocean science community has traditionally reported hypoxic limits for marine animals simply as a concentration value independent of temperature and pressure, implying the same limit for the warmest shallow gulf or the coldest deep ford. Similarly, deep-sea oxygen consumption rates are typically reported as exponential functions of depth. In implicitly combining temperature, pressure, and multiple other properties into a single variable, it becomes difficult to describe the future of an ocean under changing climate conditions. We report here on a series of recent papers that seek to provide improved descriptions, by mapping the ocean $p \mathrm{O}_{2}$ field and then matching it to the various concentration limits proposed. We describe the availability of $\mathrm{O}_{2}$ to marine animals as being governed by a diffusive boundary rate process similar to well-known descriptions of air-sea gas exchange. We also describe the challenge for a deep-sea animal exporting $\mathrm{CO}_{2}$ through the same boundary layer with known chemical reactivity imposed.

The end result is a clear sense that ocean warming in most regions will add stress to the aerobic functioning of marine life, that the oxygen minimum zones appear to be more challenging than ever, and that the deepest abyssal ocean will retain quite favorable aerobic conditions.

\section{BACKGROUND}

The concept of changing ocean chemistry with climate has emerged recently and rapidly. We now have unassailable measurements to confirm it-but it is surprising to observe how ill-prepared we are for dealing with some of the findings. In the GEOSECS (Geochemical Ocean Sections Study) decade of the 1970 s, it was common to refer to geochemical profiles as "stationary in the Eulerian sense" when describing vertical profiles-but that would be unthinkable today. The most obvious case is the recent rise in awareness of ocean acidification, although in retrospect, red flags were apparent for many decades (Brewer, 2013). In this paper we review the background of increasing awareness of changes in the ocean's chemical state over the last several decades and examine possible ways in which new metrics can be applied that attempt to incorporate fundamental physico-chemical principles. The challenge is very real: for over 50 years, ocean scientists have, for what were good reasons at the time, taken shortcuts that so comingled multiple properties that basic needs such as an explicit temperature dependence of rates has been avoided. Put very simply, we cannot predict climate change impacts on ocean chemistry if we do not our equations. Nowhere has this been more apparent than in the treatment of oceanic consumption rates of oxygen and descriptions of hypoxia.

One of the earliest estimates of oceanic oxygen consumption rates appears in a classic paper by Riley (1951), where he noted the appearance of an exponential decline in rates with depth. This paper was followed by the analysis of Wyrtki (1962) in which the formulation of biogeochemical rates as an exponential function of depth was repeated. But Wyrtki clearly understood the conundrum this presented, for he noted that " $[t]$ he consumption of oxygen is certainly dependent on the amount of oxidizable substances present," and " $t \mathrm{t}]$ emperature might have an appreciable effect, which would result in a higher consumption in the warm upper layers and in a smaller consumption in the deep colder layers, have temperature-dependent terms in but as the temperature decreases almost exponentially, like $\mathrm{e}^{-\mathrm{z}}$, such an effect would have already been included in the assumption of an exponential decrease of consumption." Thus, temperature dependence, the dominant control on chemical reaction rates, was blurred. There are good reasons for this-it is difficult to untangle the simultaneous effects of temperature, time, mixing, ventilation history, the quantity and state of organic matter present, and the effectiveness of microbial attack.

It is interesting to speculate, perhaps mischievously, how these early papers would appear had ocean chemists written them. The choice of an exponential form is near identical to the classical representations of the temperature dependence of chemical reaction rates given by van't Hoff (1884) and Arrhenius (1889), where the form for the rate constant $\mathrm{K}=\mathrm{Ae}^{-\mathrm{Q} / \mathrm{T}}$ is used, and a "pseudo" or "apparent" Arrhenius rate might then have been given. It is not surprising that this relationship has proved to be an enduring approximation to the ensemble of oxygen consumption processes. But, while this comingling of temperature with other functions can be convenient in the short term, it inevitably leads to difficulties in predicting the impacts of a warming ocean on chemical distributions and properties.

The attractiveness of a simple exponent with depth is obvious because most oceanic observations are made as vertical profiles, and, hence, the practice has endured. Munk (1966) repeated this formulation, as did Craig (1969) and Jenkins (1982). Because so many other oceanic chemical variables are so strongly correlated with oxygen consumption and the decomposition of organic matter, we find a representation of chemical variables as an exponential 
function of depth to be very widely used throughout ocean chemistry. For example, the decline in particle flux with depth as organic matter is consumed was early given as an exponent of depth in the classic treatment of sediment trap data by Knauer and Martin (1981) and Martin et al. (1987).

At this time, we really do not have a strong sense of the relative importance of the interlocked properties of increasing stratification and reduced ventilation, the changing downward flux of organic matter, and the influence of temperature dependence of reaction rates-but we can be certain that temperaturedependent rates are present. The recent Intergovernmental Panel on Climate Change Working Group 1 (IPCC WG 1) Fifth Assessment Report (Chapter 6, Ciais et al., 2013) predicts that "[it] is likely that large decreases in oceanic dissolved oxygen will occur during the $21^{\text {st }}$ century" but also notes that there are "large uncertainties in potential biogeochemical effects." However, the effects of temperature on metabolic rates are fundamental (Brown et al., 2004). In addition, while the focus has tended to be on immediate particle fluxes, the large stores of organic matter in continental shelf sediments must surely come into play as temperature rises and the diffusive flux of reduced species into the ocean increases (Gilbert et al., 2010).

More recently, quite careful analyses intended to clarify more specifically the role of temperature on water column

Peter G. Brewer (brpe123@gmail.com) is Senior Scientist, Monterey Bay Aquarium Research Institute, Moss Landing, CA, USA. Andreas F. Hofmann is on the staff at the German Aerospace Center (DLR), Institute of Technical Thermodynamics, Stuttgart, Germany. rates have appeared. For example, analyses of the extensive Joint Global Ocean Flux Study (JGOFS) data sets (Laws et al., 2000) show very clearly that temperature alone accounts for some $86 \%$ of the variance in organic matter export from the euphotic zone. Iversen and Ploug (2013) address temperature effects on respiration rates and carbon fluxes below the euphotic zone, reporting a rate change of a factor of 3.5 when the temperature is reduced by $11^{\circ} \mathrm{C}$, suggestive of a $Q_{10}$ (temperature coefficient that is a measure of the rate of change of a biological or chemical system as a consequence of increasing the temperature of the system by $10^{\circ} \mathrm{C}$ ) of about 3 . Thamdrup and Fleischer (1998) observed temperaturedependent ocean microbial rate processes with a $\mathrm{Q}_{10}$ of about 3 in the upper water column where the highest rates of $\mathrm{O}_{2}$ consumption are found. We may assume that oceanic microbes function pretty much as microbes do everywhere and, as the ocean warms, microbial oxidation rates in sediments and in the water column will increase. It would seem to make the most sense to begin by making an affirmative statement that, for a predicted ocean temperature change of $2^{\circ} \mathrm{C}$, microbial $\mathrm{O}_{2}$ reduction rates will increase by about $25 \%$; however, the net outcome may be modified by uncertainties in changes in the flux of organic matter from the surface, and the loss of $\mathrm{O}_{2}$ will be further enhanced by reduced ventilation. There are several recent careful reviews of the status of oceanic $\mathrm{O}_{2}$ (e.g., Keeling et al., 2010), but all, while providing warnings, have stopped short of invoking specific temperature dependencies.

Locally, there are exceptions to this, particularly at a depth where the flux of reduced species that is separate from the downward vertical transport can occur.
One recent example is the rapid microbial oxidation of methane and other hydrocarbons released into the deep Gulf of Mexico from the Deepwater Horizon oil spill disaster (Kessler et al., 2011), which created a persistent local oxygen anomaly. But, there, too, the rates would have been faster in warmer waters irrespective of depth. Other Earth science disciplines do not share this legacy of reliance on nontemperature-dependent functions; for example, the decay of organic matter in soils is quite specifically described as a van't Hoff/Arrhenius function of temperature (e.g., Lloyd and Taylor, 1994).

\section{EMERGING PROBLEMS}

\section{IN THE OXYGEN STATUS}

\section{OF THE OCEAN}

Very clearly, oceanic dissolved oxygen levels are declining in many, but not all, regions. Nakanowatari et al. (2007) and Stramma et al. (2008) provide welldocumented reports of temperaturerelated increasing $\mathrm{O}_{2}$ consumption rates at depth, and Helm et al. (2011) extend the analysis of these observations. The conclusion of Helm et al. (2011) reads: "Approximately 15\% of global oxygen decrease can be explained by a warmer mixed-layer reducing the capacity of water to store oxygen, while the remainder is consistent with an overall decrease in the exchange between surface waters and the ocean interior. Here we suggest that this reduction in water mass renewal rates on a global scale is a consequence of increased stratification caused by warmer surface waters."

The initial focus on reduced ventilation makes sense because it will be the first physical process to be disrupted. But the relative neglect of temperaturedependent biogeochemical rate changes at depth is of concern. By far the largest 
changes in $\mathrm{O}_{2}$ consumption occur not at great depth but rather immediately below the euphotic zone where climatic warming is already apparent. The chemical function of reduced solubility with rising temperature accounts for only $\sim 15 \%$ of the observed change. The solubility dependence of $\mathrm{O}_{2}$ is close to $14.7 \mu \mathrm{mol} \mathrm{kg}{ }^{-1}$ for warming from $4^{\circ} \mathrm{C}$ to $6^{\circ} \mathrm{C}$ (a typical $\mathrm{O}_{2}$ minimum example), and many areas of the ocean today have far lower concentrations of $\mathrm{O}_{2}$ than this (Thamdrup et al., 2012; Ulloa et al., 2012). If the changes at depth of the consumption terms were to mirror the temperature dependence of the biogeochemical export flux from the euphotic zone noted by Laws et al. (2000), and in the future account for $85 \%$ of the signal, then we could face very large-scale reductions of oceanic oxygen.

\section{DEFINITIONS OF HYPOXIA}

The traditional lack of specific temperature terms in describing deep-ocean oxygen consumption appears to have been carried through to descriptions of impacts of lowered oxygen levels on marine life.

Hofmann et al. (2011) report on the confusing definitions of oceanic hypoxia. It is possible to find a huge range of temperature-independent claims. For example, Table 1 of Hofmann et al. (2011) includes some 28 references to the various definitions of hypoxia, in varying units, and none contain temperature- or depth-dependent terms. Although all of these definitions and observed limits have some well-intentioned basis, the end result is great confusion. For example, Diaz and Rosenberg (2008) report that mass mortality occurs at $0.7 \mathrm{ml} \mathrm{L}^{-1} \mathrm{O}_{2}$. This figure is equivalent to $31.3 \mu \mathrm{mol} \mathrm{L}{ }^{-1}$. Huge oceanic areas with abundant marine life occur within this boundary, and the same limit is implied for warm surface waters or cold, deep fjords.

The term "dead zone" has been widely used and is recognized in the popular press. It has been used to describe the low-oxygen episodes in the Gulf of Mexico (Rabalais et al., 2010) and has been set at $61 \mu \mathrm{mol} \mathrm{L}{ }^{-1}$, about twice the level reported by Diaz and Rosenberg (2008), again without temperature for physical scientists to use this information for oceanic assessments of climate change impacts, where temperature is a prime variable, or to deal in any useful way with this literature in its present form. Marine animals display wide variation in how they adapt to the particular external temperature and oxygen regimes of their niches. All animals are subject to the same physico-chemical laws that characterize the now-changing

\section{...WE CANNOT PREDICT CLIMATE CHANGE IMPACTS ON OCEAN CHEMISTRY IF WE DO NOT HAVE TEMPERATURE-DEPENDENT TERMS IN OUR EQUATIONS.}

dependence. This stress level was found to be too stringent by Vaquer-Sunyer and Duarte (2008), who doubled it yet again to $4.6 \mathrm{mg} \mathrm{O}_{2} \mathrm{~L}^{-1}$, or $144 \mu \mathrm{mol} \mathrm{L}{ }^{-1}$ _but vast oceanic fisheries exist within this oxygenated space. A possibly higher cautionary level was set by Gray et al. (2002), who reported that "growth is affected" at oxygen levels between 181 and $140 \mu \mathrm{mol} \mathrm{L}^{-1}$. The range of values from $31-181 \mu \mathrm{mol} \mathrm{L}{ }^{-1}$ with no specified temperature or pressure dependence appears unusual. We have also not been able to find any reference to the accompanying $\mathrm{CO}_{2}$ levels in setting these limits. This appears odd, given the attention now paid to impacts of rising oceanic $\mathrm{CO}_{2}$ levels and the expressed concerns over elevated $\mathrm{CO}_{2}$ levels on deep-sea animal aerobic functioning (Seibel and Walsh, 2003).

The focus of the above articles is to report on the observed impacts of changing $\mathrm{O}_{2}$ concentrations on various forms of marine life. It is very difficult external boundary conditions. They cannot control their environments, but must react to them. We need better descriptors of these physical and chemical conditions.

\section{THE EXTERNAL OCEANIC BOUNDARY CONDITION FOR A MARINE ORGANISM Partial Pressure of $\mathrm{O}_{2}$} In a first effort to address some of these concerns, Hofmann et al. (2011) mapped the oceanic oxygen field with $\mathrm{pO}_{2}$ rather than concentration as a variable. This method has the advantage that temperature and pressure terms are now formally incorporated into the observed fields. Geochemists have long produced fields of oceanic $p \mathrm{CO}_{2}$ (Takahashi et al., 1981), and it makes perfect sense to compare them to maps of $\mathrm{pO}_{2}$. In one very early example of response to the need for better definition of physical and chemical conditions and its relationship to biological impacts, Redfield and 
Goodkind (1929) tested the lethal limits for a squid in the laboratory in terms of the $p \mathrm{O}_{2}$ to $p \mathrm{CO}_{2}$ ratio. There are already regions in the ocean where $p \mathrm{CO}_{2}>p \mathrm{O}_{2}$ (Brewer and Peltzer, 2009), likely posing stress beyond that characterized by $\mathrm{O}_{2}$ concentration alone. These regions will surely grow in size.

The first challenge Hofmann et al. (2011) faced was to guess at the temperature implied in the various definitions of hypoxia that are based on concentration alone. Figure 1 shows a specific example of this by comparing the various thresholds proposed against a hydrographic station off the coast of Southern California with assumed temperature values. As the ocean is now changing in both temperature and $\mathrm{O}_{2}$, such details will become critical if meaningful changes are to be described.
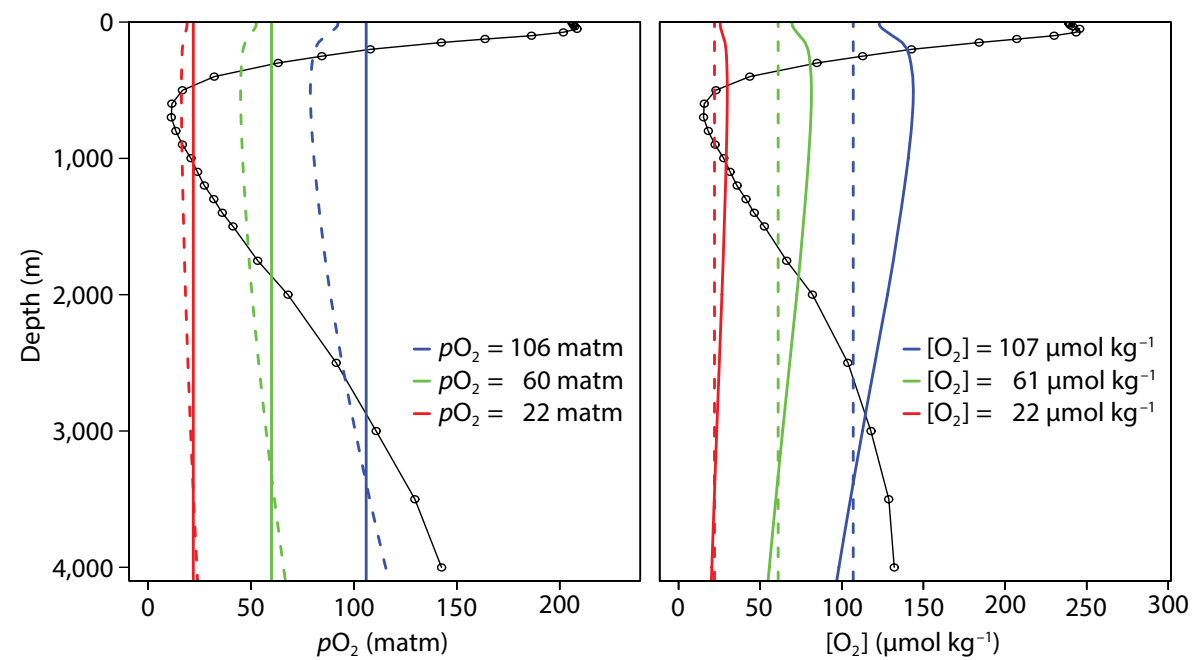

Figure 1. Dissolved oxygen profiles expressed as $\mathrm{pO}_{2}$ (left panel) and $\left[\mathrm{O}_{2}\right]$ (right panel) for an example station off the coast of Southern California $\left(29.5^{\circ} \mathrm{N}, 120.5^{\circ} \mathrm{W}\right)$ obtained from the World Ocean Atlas 2009 oxygen climatology (Garcia et al., 2010), overlaid with thresholds for hypoxia categories (blue, green, and red lines). Solid lines $=$ constant $p \mathrm{O}_{2}$ thresholds. Dashed lines $=$ constant $\left[\mathrm{O}_{2}\right]$ thresholds. To be consistent with the literature (e.g., Levin et al., 2009; Rabalais et al., 2010), $\approx 2 \mathrm{mg} \mathrm{O}_{2} \mathrm{~L}^{-1} \approx 61 \mu \mathrm{mol} \mathrm{kg}{ }^{-1}$ is equivalent to $30 \%$ saturation, which implies $\mathrm{T}=25^{\circ} \mathrm{C}$. $\mathrm{T}=25^{\circ} \mathrm{C}$ has been used to convert thresholds between $p \mathrm{O}_{2}$ and $\left[\mathrm{O}_{2}\right]$; however, the ambient surface temperatures at the example station are $\approx 17.6^{\circ} \mathrm{C}$, and thus, the constant $p \mathrm{O}_{2}$ and constant $\left[\mathrm{O}_{2}\right]$ threshold lines do not meet at the surface. The results show very clearly the wide range of hypoxia estimates; the red line is the severe hypoxia category of about $22 \mu \mathrm{mol} \mathrm{kg}^{-1}$. This is twice the standard geochemical value of $10 \mu \mathrm{mol} \mathrm{kg}{ }^{-1}$ that is typically taken to characterize the onset of suboxic conditions where onset of $\mathrm{NO}_{3}$ reduction occurs. It is clear that a very wide range of depths may be described as hypoxic, depending on the definition given. From Hofmann et al. (2011) molecular diffusion coefficient for $\mathrm{O}_{2}$ in $\mathrm{cm}^{2} \mathrm{~s}^{-1}, L$ is the thickness of the diffusive boundary layer in centimeters, $\rho_{s w}$ is the in situ density of seawater, and $\left.\Delta p \mathrm{O}_{2}\right|_{\mathrm{DBL}}$ is the $\mathrm{pO}_{2}$ gradient across the $\mathrm{DBL}$, calculated using the standard form of Henry's Law and corrected for pressure as in Enns et al. (1965). The thickness L of the DBL is a critical property and, as with the well-known air-sea exchange rate functions, can be approximated by a simple planar model using laminar flow.

From these terms, we can describe a purely physical (organism-independent) property that characterizes as an upper limit the maximum oceanic "oxygen supply potential" per unit area of exposed respiratory surface. Note that the quantity represents a theoretical maximum as we approximate $\left.\Delta p \mathrm{O}_{2}\right|_{\text {DBL }}$ by the oxygen partial pressure in the free stream around the animal $\left[p \mathrm{O}_{2}\right] \mathrm{f}$. The supply potential $\mathrm{SP}_{\mathrm{O}_{2}}$ is given by

$\mathrm{SP}_{\mathrm{O}_{2}}:=\left.D \rho_{s w} K O^{\prime} p \mathrm{O}_{2}\right|_{\mathrm{f}}=D \rho_{s w}\left[\mathrm{O}_{2}\right]_{\mathrm{f}}$.

Figure 2 shows examples of the oceanic distribution of this property.

It is very clear that flow over an animal's surface, whether actively driven by species-induced flow or resulting from motions in the external ocean, is a critical property. As with increased wind speed at the air-sea interface, this flow increases the gas exchange rate. It is a highly nonlinear function of flow typically characterized by the Schmidt number.

This analysis shows that there will be a cascade of effects resulting from ocean warming. Gases are less soluble in warmer water, and although water in contact with the atmosphere has a $\mathrm{pO}_{2} \approx 0.21 \mathrm{~atm}$, once a water parcel has left the surface with its lesser $\mathrm{O}_{2}$ mass, respiratory $\mathrm{O}_{2}$ consumption will occur and interior $\mathrm{O}_{2}$ levels will decline. Considering again only the external 
functions, an animal at depth will experience some benefits from the warmer water: molecular diffusion terms will increase, thus increasing $\mathrm{O}_{2}$ transport through the diffusive boundary layer, but it will also be exposed to lower external $\mathrm{O}_{2}$ levels. Which effect has the greater impact? The answer is that the lowered $\mathrm{O}_{2}$ levels dominate by far, and, in most, but not all cases, there will be increased difficulty in maintaining the desired $\mathrm{O}_{2}$ supply rate.

Figure 3 shows one example of these effects. It graphs the relationship between the oxygen concentration required at the surface to support a given uptake rate against the equivalent concentration at depth, assuming a flow rate over the surface of $2 \mathrm{~cm} \mathrm{sec}^{-1}$. The calculation requires inclusion of the Henry's Law constants for in situ conditions and can be used to compare warm and shallow to cold and deep conditions (Hofmann et al., 2013a). The result shows that for typical ocean depthtemperature profiles, the equivalent $\mathrm{O}_{2}$ profiles require about three times greater $\mathrm{O}_{2}$ concentration at $1,000 \mathrm{~m}$ depth as at the surface in order to have $\mathrm{O}_{2}$ supplied at the same rate. Because $\mathrm{O}_{2}$ concentrations in nature decline rapidly with depth, there is double jeopardy-the absolute decline in concentration of dissolved $\mathrm{O}_{2}$ and greater physical difficulty in gaining access to what is there.

\section{The Added Impact of} Rising $\mathrm{CO}_{2}$ Levels

Ocean acidification is now widely recognized as an emerging ocean environmental stress (IPCC, 2011). Concerns have been expressed that rising $\mathrm{CO}_{2}$ levels will adversely affect deep-sea animal aerobic functioning and will thus negatively interact with oxidative stress. For example, Seibel and Walsh (2003), in comments addressing the possible ocean (Brewer et al., 1999), noted that “[o]xygen transport proteins of deep sea animals are also highly sensitive to capture and storage in the ocean, as first advanced by Marchetti (1977), Caldeira et al. (2005) reported that "[a]cute $\mathrm{CO}_{2}$ exposure causes acidification of the blood, will hamper oxygen uptake and binding at the gills and reduce the amount of oxygen carried in the blood, limiting performance and at high concentrations could cause death." Thus, it seems wise to investigate the problem of animal export of $\mathrm{CO}_{2}$ within the same physical framework of a boundary layer gas exchange process as we do for import of $\mathrm{O}_{2}$.

Hofmann et al. (2013b) tackled this problem, with the physical description of the external boundary layer and its relationship to flow over the surface remaining the same. The key difference direct disposal of fossil fuel $\mathrm{CO}_{2}$ in the changes in $\mathrm{pH}$." In the context of carbon

lies in the chemical reaction rates. Dissolved $\mathrm{O}_{2}$ is inert during its diffusive transport through the boundary layer and into the animal tissue, but the $\mathrm{CO}_{2}$ molecule exported from the animal tissue surface is highly reactive with water. The reacto-diffusive equations describing this process can be complex. In completing a thorough analysis of this problem, Hofmann et al. (2013b) found that very useful simplifications can be made in a manner analogous to those described by Emerson (1975) and Zeebe and Wolf-Gladrow (2001).

The essential argument is that upon transfer of the free $\mathrm{CO}_{2}$ molecule from the tissue to the surrounding seawater, a chemical reaction initiates, forming bicarbonate ion. Although the reaction rates of $\mathrm{CO}_{2}$ with water are notoriously slow at low temperature and typical seawater $\mathrm{pH}$, the rates are not zero. Some $\mathrm{CO}_{2}$ is consumed, slightly lowering $p \mathrm{CO}_{2}$ at the tissue's outer surface. The $p \mathrm{CO}_{2}$ difference across the boundary
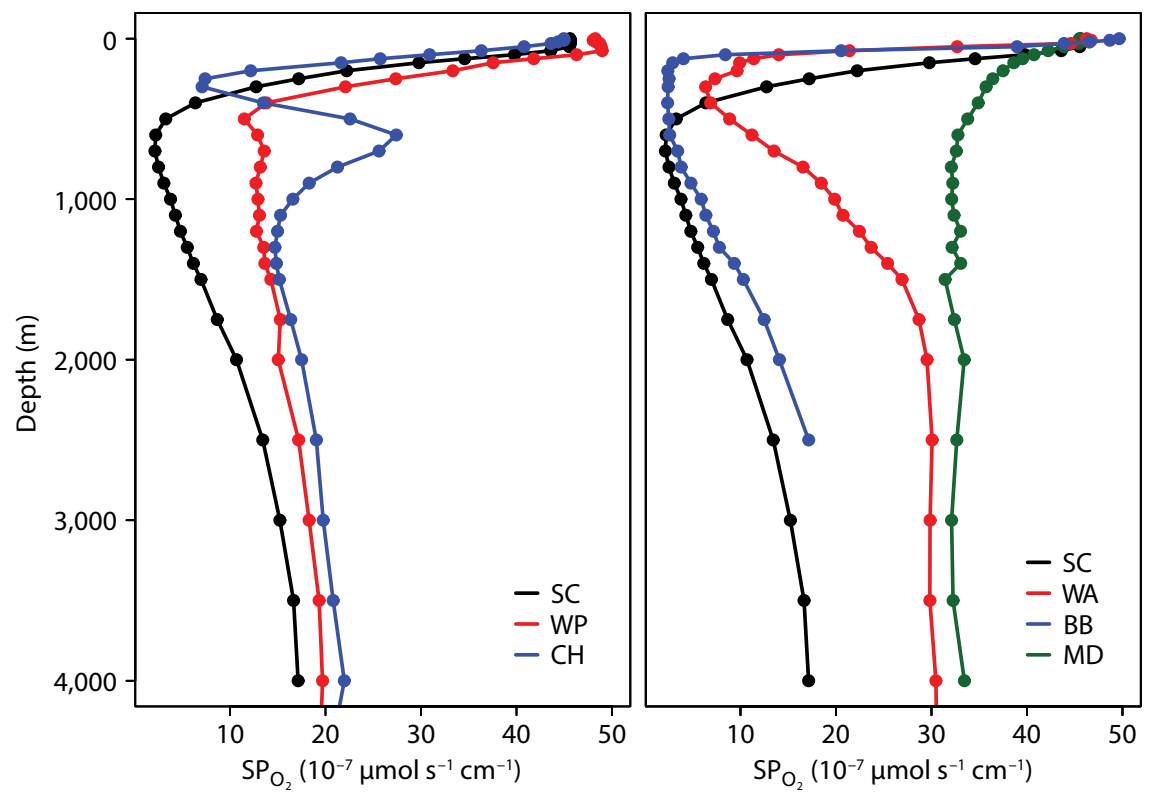

Figure 2. Oxygen supply potential $\mathrm{SP}_{\mathrm{O}_{2}}$ depth profiles of the water column at different hydrographic stations around the world. SC = Southern California $\left(29.5^{\circ} \mathrm{N}, 120.5^{\circ} \mathrm{W}\right)$. $\mathrm{CH}=$ Chile $\left(33.5^{\circ} \mathrm{S}, 75.5^{\circ} \mathrm{W}\right)$. WP $=$ Western Pacific $\left(11.5^{\circ} \mathrm{N}, 126.5^{\circ} \mathrm{E}\right)$. WA = Western Africa $\left(15.5^{\circ} \mathrm{S}, 6.5^{\circ} \mathrm{E}\right) \cdot \mathrm{MD}=$ Mediterranean $\left(35.5^{\circ} \mathrm{N}, 18.5^{\circ} \mathrm{E}\right) . \mathrm{BB}=$ Bay of Bengal $\left(18.5^{\circ} \mathrm{N}, 87.5^{\circ} \mathrm{E}\right)$. From Hofmann et al. (2013a) 
layer provides the chemical driving force, and this reaction steepens the diffusional gradient, enhancing the outgoing flux. The simplest way to describe this process is by encapsulating the complex of chemical variables into a dimensionless Enhancement Factor (EF),

$\mathrm{EF}=\frac{E^{\mathrm{CO}_{2}}}{E_{\mathrm{diff}^{2}}^{\mathrm{CO}_{2}}}=f\left(L^{\mathrm{CO}_{2}}, T, S, P, \mathrm{pH}_{\text {free scale }}\right)$

where $E^{\mathrm{CO}_{2}}$ represents the true $\mathrm{CO}_{2}$ flux, including the effects of chemical reactions, and $E_{\text {diff }}^{\mathrm{CO}_{2}}$ is the hypothetical diffusive flux that would occur if $\mathrm{CO}_{2}$ were not chemically reactive in seawater.

The net result is that the diffusive efflux of respiratory $\mathrm{CO}_{2}$ is always physically faster than the equivalent $\mathrm{O}_{2}$ influx. Even with very high external oceanic $p \mathrm{CO}_{2}$ conditions, this relationship will remain true. Put simply, while it is clearly physically possible for a marine animal to increase access to dissolved $\mathrm{O}_{2}$ by increasing the flow over its surface, it would be very difficult to rid itself of excess $\mathrm{CO}_{2}$ by this tactic, as the efflux is not diffusion limited. Internal $\mathrm{pH}$ compensation would be a better strategy. In practice, deep-sea animals have evolved significant internal $\mathrm{pH} / \mathrm{CO}_{2}$ compensating mechanisms. It is logical to think that this may be due to the limitations posed by the external ocean boundary reacto-diffusive chemistry.

\section{DISCUSSION}

Physico-chemical processes based on temperature, hydrostatic pressure, and boundary layer effects play a significant role in defining the accessibility of $\mathrm{O}_{2}$ for marine organisms.

The combination of varying temperature and depth with oceanic $\mathrm{O}_{2}$ concentrations via fundamental rules such as Henry's Law and diffusion rates provides us with a fresh look and allows a more formal estimate of possible climate
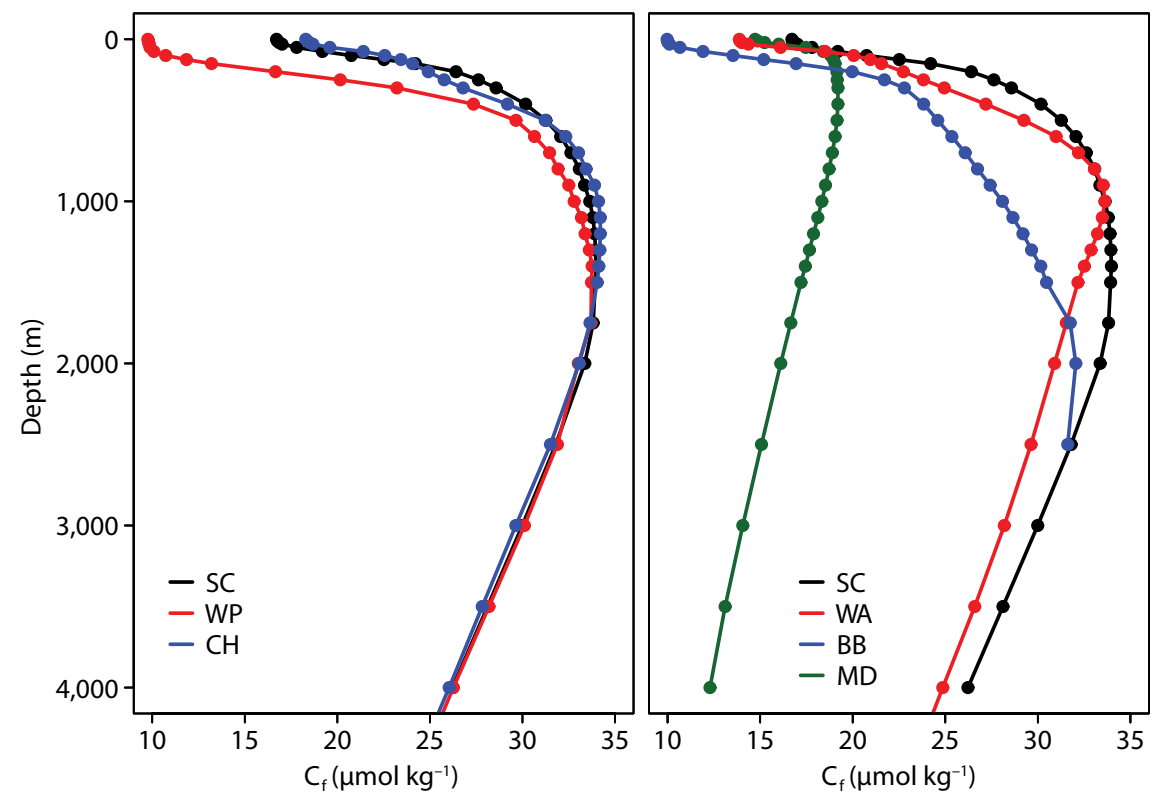

Figure 3. An example of the effects of temperature and pressure with depth-the minimal oxygen concentration $\left(C_{f}\right)$ a given animal needs to survive (for an exact definition of $C_{f}$, see Hofmann et. al., 2013a). Depth profiles of the water column are from different hydrographic stations around the world. SC $=$ Southern California $\left(29.5^{\circ} \mathrm{N}, 120.5^{\circ} \mathrm{W}\right) . \mathrm{CH}=$ Chile $\left(33.5^{\circ} \mathrm{S}, 75.5^{\circ} \mathrm{W}\right) \cdot \mathrm{WP}=$ Western Pacific $\left(11.5^{\circ} \mathrm{N}, 126.5^{\circ} \mathrm{E}\right) . \mathrm{WA}=$ Western Africa $\left(15.5^{\circ} \mathrm{S}\right.$, $\left.6.5^{\circ} \mathrm{E}\right) \cdot \mathrm{MD}=$ Mediterranean $\left(35.5^{\circ} \mathrm{N}, 18.5^{\circ} \mathrm{E}\right) . \mathrm{BB}=$ Bay of Bengal $\left(18.5^{\circ} \mathrm{N}, 87.5^{\circ} \mathrm{E}\right)$. A generic flow velocity of $u 100=2 \mathrm{~cm} \mathrm{~s}^{-1}$ is assumed for all depths. 
Working Group I Contribution to the IPCC Fifth Assessment Report, Climate Change 2013: The Physical Science Basis. Available online at: http://www.climatechange2013.org/images/ uploads/WGIAR5_WGI-12Doc2b_FinalDraft_ Chapter06.pdf (accessed December 11, 2013).

Craig, H. 1969. Abyssal carbon and radiocarbon in the Pacific. Journal of Geophysical Research 74:5,491-5,506, http://dx.doi.org/ 10.1029/JC074i023p05491.

Diaz, R.J., and R. Rosenberg. 2008. Spreading dead zones and consequences for marine ecosystems. Science 321:926-929, http://dx.doi.org/10.1126/ science.1156401.

Emerson, S. 1975. Chemically enhanced $\mathrm{CO}_{2}$ gas exchange in a eutrophic lake: A general model. Limnology \& Oceanography 20:743-761, http:// dx.doi.org/10.4319/lo.1975.20.5.0743.

Enns, T., P.F. Scholander, and E.D. Bradstreet. 1965. Effect of hydrostatic pressure on gases dissolved in water. Journal of Physical Chemistry 69:389-391, http://dx.doi.org/ 10.1021/j100886a005.

Garcia, H.E., R.A. Locarnini, T.P. Boyer, J.I. Antonov, O.K. Baranova, M.M. Zweng, and D.R. Johnson. 2010. World Ocean Atlas 2009, Volume 3: Dissolved Oxygen, Apparent Oxygen Utilization, and Oxygen Saturation. S. Levitus, ed., NOAA Atlas NESDIS 70, US Government Printing Office, Washington, DC, 344 pp. Available online at: ftp://ftp.nodc.noaa.gov/pub/ WOA09/DOC/woa09_vol3_text.pdf (accessed December 2, 2013).

Gilbert, D., N.N. Rabalais, R.J. Diaz, and J. Zhang. 2010. Evidence for greater oxygen decline rates in the coastal ocean than in the open ocean. Biogeosciences 7:2,283-2,296, http://dx.doi.org/ 10.5194/bg-7-2283-2010.

Gray, J.S., R. Shiu-sun, and Y.Y. Or. 2002. Effects of hypoxia and organic enrichment on the coastal marine environment. Marine Ecology Progress Series 238:249-279, http://dx.doi.org/10.3354/ meps238249.

Helm, K.P., N.L. Bindoff, and J.A. Church. 2011. Observed decreases in oxygen content of the global ocean. Geophysical Research Letters 38, L23602, http://dx.doi.org/10.1029/ 2011 GL049513.

Hofmann, A.F., E.T. Peltzer, and P.G. Brewer. 2013a. Kinetic bottlenecks to chemical exchange rates for deep-sea animals - Part I: Oxygen. Biogeosciences 10:13,817-13,856, http://dx.doi.org/10.5194/bgd-9-13817-2012.

Hofmann, A.F., E.T. Peltzer, and P.G. Brewer. 2013b. Kinetic bottlenecks to chemical exchange rates for deep-sea animals - Part II: Carbon dioxide. Biogeosciences 10:2,409-2,425, http://dx.doi.org/10.5194/bg-10-2409-2013.

Hofmann, A.F., E.T. Peltzer, P.M. Walz, and P.G. Brewer. 2011. Hypoxia by degrees: Establishing definitions for a changing ocean. Deep Sea Research Part I 58:1,212-1,226, http:// dx.doi.org/10.1016/j.dsr.2011.09.004.

IPCC (Intergovernmental Panel on Climate Change). 2011. IPCC Workshop on Impacts of Ocean Acidification on Marine Biology and Ecosystems. Workshop report, January 17-19,
2011, Okinawa, Japan. C.B. Field, V. Barros, T.F. Stocker, Q. Dahe, K.J. Mach, G.-K. Plattner, M.D. Mastrandrea, M. Tignor, and K.L. Ebi, eds, 164 pp. Available online at: http:// www.ipcc-wg2.gov/meetings/workshops/ OceanAcidification_WorkshopReport.pdf (accessed December 2, 2013).

Iversen, M.H., and H. Ploug. 2013. Temperature effects on carbon-specific respiration rates and sinking velocity of diatom aggregates: Potential implications for deep ocean export processes. Biogeosciences 10:4,073-4,085, http:// dx.doi.org/10.5194/bg-10-4073-2013.

Jenkins, W.J. 1982. Oxygen utilization rates in the North Atlantic subtropical gyre and primary production in oligotrophic systems. Nature 300:246-248, http://dx.doi.org/ $10.1038 / 300246 a 0$.

Keeling, R.F., A. Körtzinger, and N. Gruber. 2010. Ocean deoxygenation in a warming world. Annual Review of Marine Science 2:199-229, http://dx.doi.org/10.1146/annurev.marine. 010908.163855.

Kessler, J.D., D.L. Valentine, M.C. Redmond, M. Du, E.W. Chan, S.D. Mendes, E.W. Quiroz, C.J. Villanueva, S.S. Shusta, L.M. Werra, and others. 2011. A persistent oxygen anomaly reveals the fate of spilled methane in the deep Gulf of Mexico. Science 331:312-315, http:// dx.doi.org/10.1126/science.1199697.

Knauer, G.A., and J.H. Martin. 1981. Primary production and carbon-nitrogen fluxes in the upper $1500 \mathrm{~m}$ of the Northeast Pacific. Limnology \& Oceanography 26:181-182, http:// dx.doi.org/10.4319/lo.1981.26.1.0181.

Laws, E.A., P.G. Falkowski, W.O. Smith, H. Ducklow, and J.J. McCarthy. 2000. Temperature effects on export production in the open ocean. Global Biogeochemical Cycles 14:1,231-1,246, http://dx.doi.org/ 10.1029/1999GB001229.

Levin, L.A., W. Ekau, A.J. Gooday, F. Jorissen, J.J. Middelburg, S.W.A. Naqvi, C. Neira, N.N. Rabalais, and J. Zhang. 2009. Effects of natural and human-induced hypoxia on coastal benthos. Biogeosciences 6:2,063-2,098, http:// dx.doi.org/10.5194/bg-6-2063-2009.

Lloyd, J., and J.A. Taylor. 1994. On the temperature dependence of soil respiration. Functional Ecology 8:315-323, http://dx.doi.org/10.2307/ 2389824.

Marchetti, C. 1977. On geoengineering and the $\mathrm{CO}_{2}$ problem. Climatic Change 1:59-68, http://dx.doi.org/10.1007/BF00162777.

Martin, J.H., G.A. Knauer, D.M. Karl, and W.W. Broeknow. 1987. VERTEX: Carbon cycling in the Northeast Pacific. Deep Sea Research Part A 34:267-285, http://dx.doi.org/ 10.1016/0198-0149(87)90086-0.

Munk, W.H. 1966. Abyssal recipes. Deep Sea Research 13:707-730, http://dx.doi.org/ 10.1016/0011-7471(66)90602-4.

Nakanowatari, T., K.I. Ohshima, and M. Wakatsuchi. 2007. Warming and oxygen decrease of intermediate water in the northwestern North Pacific, originating from the
Sea of Okhotsk, 1955-2004. Geophysical Research Letters 34, L04602, http://dx.doi.org/ 10.1029/2006GL028243.

Rabalais, N.N., R.J. Diaz, L.A. Levin, R.E. Turner, D. Gilbert, and J. Zhang. 2010. Dynamics and distribution of natural and human-caused hypoxia. Biogeosciences 7:585-619, http:// dx.doi.org/10.5194/bg-7-585-2010.

Redfield, A.C., and R. Goodkind. 1929. The significance of the Bohr effect in the respiration and asphyxiation of the squid, Loligo Pealei. Journal of Experimental Biology 6:340-349, http://jeb. biologists.org/content/6/4/340.short.

Riley, G.A. 1951. Oxygen, phosphate, and nitrate in the Atlantic Ocean. Bingham Oceanographic Laboratory Bulletin, vol. 13. Peabody Museum of Natural History, Yale University, 126 pp.

Seibel, B.A., and P.J. Walsh. 2003. Biological impacts of deep-sea carbon dioxide injection inferred from indices of physiological performance. Journal of Experimental Biology 206:641-650, http://dx.doi.org/10.1242/ jeb.00141.

Stramma, L., G.C. Johnson, J. Sprintall, and V. Mohrholz. 2008. Expanding oxygen minimum zones in the tropical oceans. Science 320:655-658, http://dx.doi.org/ 10.1126/science.1153847.

Thamdrup, B., and S. Fleischer. 1998. Temperature dependence of oxygen respiration, nitrogen mineralization, and nitrification in Arctic sediments. Aquatic Microbial Ecology 15:191-199, http://dx.doi.org/10.3354/ame015191.

Thamdrup, B., T. Dalsgaard, and N.P. Revsbech. 2012. Widespread functional anoxia in the oxygen minimum zone of the eastern south Pacific. Deep Sea Research Part I 65:36-45, http://dx.doi.org/10.1016/j.dsr.2012.03.001.

Takahashi, T., W.S. Broecker, and A.E. Bainbridge. 1981. The alkalinity and total carbon dioxide concentration in the world oceans. Pp. 271-286 in Carbon Cycle Modeling. B. Bolin, ed., SCOPE Volume 16, J. Wiley \& Sons, New York.

Ulloa, O., D. Canfield, E.F. DeLong, R.M. Letelier, and F.J. Stewart. 2012. Microbial oceanography of anoxic oxygen minimum zones. Proceedings of the National Academy of Sciences of the United States of America 109:15,996-16,003, http://dx.doi.org/10.1073/pnas.1205009109.

van't Hoff, J.H. 1884. Etudes de dynamique chemique. Frederick Muller \& Co., Amsterdam.

Vaquer-Sunyer, R., and C.M. Duarte. 2008. Thresholds of hypoxia for marine biodiversity. Proceedings of the National Academy of Sciences of the United States of America 105(40):15,452-15,457, http:// dx.doi.org/10.1073/pnas.0803833105.

Wyrtki, K. 1962. The oxygen minima in relation to ocean circulation. Deep Sea Research 9:11-23, http://dx.doi.org/ 10.1016/0011-7471(62)90243-7.

Zeebe, R.E., and D. Wolf-Gladrow. 2001. $\mathrm{CO}_{2}$ in Seawater: Equilibrium, Kinetics, Isotopes. Elsevier Oceanography Series, vol. 65, Elsevier, 1st ed. 